\title{
Tennessee valley energy
}

\author{
The Tennessee Valley Authority represents an \\ American historical landmark. Colin Norman reports
}

\section{WHEN the Tennessee Valley}

Authority (TVA) was established in 1933, at the height of the great depression, it rapidly became one of the more controversial instruments of President Franklin D. Roosevelt's famed New Deal. Designed, in Roosevelt's words, for the reclamation of land and of human beings, the creation of TVA was a unique federal attempt to attack the grinding poverty of an entire region by developing and conserving its natural resources.

Like much of the New Deal, the experiment was controversial because it went against the capitalist grain for the federal government to play such a strong role in economic and social enterprises. To many conservatives, it smacked of socialism. Now, 43 years later, TVA is still controversial, though for different reasons.

In 1933, the Tennessee Valley was an economic and environmental disaster area. Most of the region's people were at the bottom of the pile, living in desperate poverty. The land, which had been worked to death, was fast being eroded and turned into a barren waste. The hillsides, which once boasted the largest hardwood forests in Nonth America, were denuded. And the 1,000-mile Tennessee River would frequently burst its banks, flooding vast areas; in many places, shoals and shallows also made it impossible to navigate. Then along came TVA's armies of engineers, scientists and agriculturalists to dam up the rivers, reforest the hillsides and reclaim the land. By most measures, they have been spectacularly successful.

Although family income in the region is still a little below the national average, it is no longer an economically depressed area. It has a productive agricultural system and industries have been attracted into the area by cheap electricity rates. And the Tennessee River has been tamed by numerous dams, so that it is navigable and it no longer rampages through the fields and towns each spring. The stark before-and-after contrast in the valley in fact gradually made true believers of all but the most diehard conservatives.

Consequently, TVA is now held in the highest regard by many of the people who live in the seven-state area which it serves, a fact painfully discovered by Senator Barry Goldwater in 1964 and by Ronald Reagan a few months ago. Both hinted that, if elected President, they may consider selling TVA off to private industry to get rid of this socialist monstrosity. They paid dearly at the polls as a result, losing important elections in Tennessee.

\section{Highly charged issues}

TVA is controversial now because it is facing many highly charged issues endemic to an industrial society, such as energy planning, strip mining, air pollution, and public participation in governmental decision-making. The sheer scale of TVA's operations ensures that the way it tackles those issues often has national implications.

A description of TVA's activities reads like a list of superlatives. It is the largest energy supplier in the United States, providing electricity to a region the size of Great Britain. It is the single largest user of coal in the nation, consuming more than 40 million tons a year in its power plants. It has more nuclear power plants under construction than any other electric utility. The 33 major dams which have been constructed on the Tennessee River and its tributaries harness lakes whose combined shorelines are longer than those of the Great Lakes. And it is the region's largest employer, providing 31,000 jobs.

Even the criticisms being levelled at TVA are impressive in their scope. During Senate testimony on TVA last year, for example, one critic suggested that "the Tennessee Valley Authority is a part of the problem in Appalachia, not a part of the solution", while another stated that TVA "began as an experiment in democracy but has turned into an example of how our government can practise colonialism on its own people".

TVA is really two separate operations. One, financed entirely by federal appropriations of more than $\$ 100$ million a year, is responsible for running a vast range of programmes, including agricultural assistance, fertilizer research and development, and the management of parks, dams and recreational facilities. The other, more controversial, side of 'TVA's activities is its role as supplier of electricity to the region. It is a self-supporting, $\$ 1,000$ million-a-year operation, financed by revenues and by the sale of bonds for capital projects.

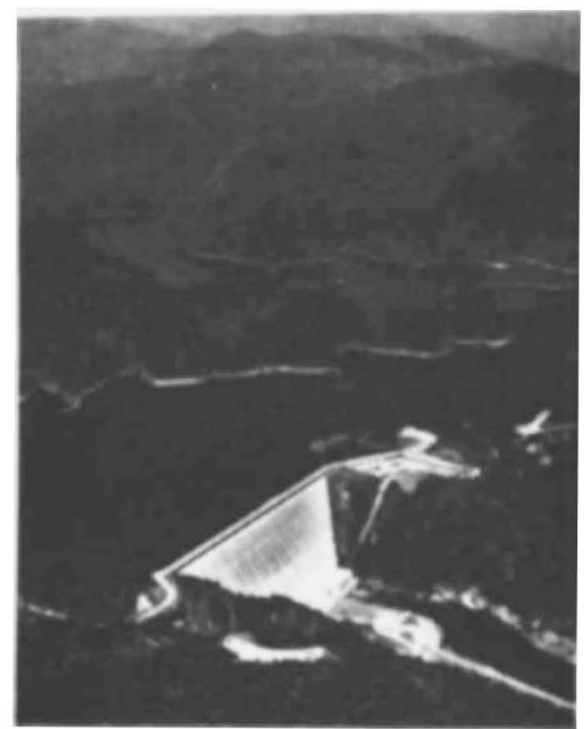

Fontana dam, the TVA's highest

Problems, controversies

The problems and controversies encountered by TVA's energy operations are similar to those being faced by other electric utility companies, but TVA's unique structure gives it some advantages in tackling them. For one thing, the agency's Congressional charter requires that it be run as a nonprofit enterprise, which means that it doesn't have to pay dividends to stockholders. It is also fortunately situated right next door to the Appalachian coal fields, and its numerous dams provide a secure source of cheap electricity. For those reasons, TVA's electricity is the cheapest in the country, selling at about $60 \%$ of the national average.

At present, about $20 \%$ of TVA's power comes from hydroelectric sources, and the rest comes from coalfired power stations. A few years ago, however, the agency decided that all its future energy growth would come from nuclear power plants, and it embarked on a massive nuclear construction programme. By the mid1980s, TVA expects to have 17 nuclear reactors in operation at seven different sites, adding up to a staggering $20,000 \mathrm{MW}$. It would be the largest user of nuclear power in the country. Clearly, TVA's espousal of the atom, at a time when many other electric utilities are deferring or cancelling their nuclear orders, has enormous impact on the United States nuclear power programme.

Why does a utility which is sitting on top of a vast coal field decide to go nuclear? TVA has already dammed up most of the rivers in the region so that there is virtually no scope for expanding its hydroelectric generating capacity. "The choice is between coal and nuclear", says TVA General Manager Lynn Seeber, "and we believe 
that nuclear will be cheaper and environmentally more acceptable". The agency's critics disagree, however, pointing out that TVA's brief experience so far with nuclear power has been disastrous-it owns and operates the Browns Ferry plant which caught fire last year-and the critics also argue that the cost estimates will prove to be grossly inaccurate.

$\mathrm{Be}$ that as it may, environmental factors clearly played a key role in TVA's decision to opt for nuclear power instead of expanding its coalfired generating capacity. In short, federal pollution control regulations are becoming more and more expensive to meet, particularly since TVA recently lost a major court battle with the Environmental Protection Agency (EPA).

\section{Regulation problems}

The pollution control regulations which are causing TVA most of its problems are embodied in the 1970 Clean Air Act, a bill which sets air quality standards and a timetable for meeting them. In some places, the Act is a little fuzzy in its definitions, and there has been a royal battle on several fronts over compliance with the standards. TVA decided early on that it could meet the regulations by a combination of tall smokestacks on its power plants, and continuous meteorological monitoring to ensure that the pollutants are not blown back to the ground in large concentrations.

It developed a sophisticated forecasting and monitoring system which would automatically give orders to curtail, or shut down entirely, individual power plants when meteorological conditions prevent proper dispersal of the stack gases. TVA has recently computerised the entire operation.

EPA interpreted the Clean Air Act differently, however, insisting that it requires stack gases, such as sulphur dioxide, to be removed entirely. Simply spewing them into the atmosphere through tall stacks will cause problems downwind, when the $\mathrm{SO}_{2}$ is washed out of the atmosphere as so-called acid rain, EPA argued. As usual in such matters, the dispute ended up in the courts and the outcome was closely watched by environmentalists and by industry since it represented a crucial test of EPA's strategies.

TVA lost the battle earlier this year. According to TVA officials, it will cost about $\$ 250$ million a year to install and operate the required pollution control equipment on several power plants. By contrast, TVA's proposed meteorological approach would have cost about $\$ 20$ million a year.

And there have been other problems with TVA's heavy use of coal. For one thing, coal prices have escalated from about $\$ 10$ to $\$ 30$ per ton in the past three years. And for another, most of TVA's coal comes from strip mines, which are causing considerable environmental destruction and bitter resentment in some areas of Appalachia.

Although TVA officials take deserved pride in the fact that all their contracts with coal suppliers contain a clause requiring that strip mined lands be restored and revegetated, it's clear from testimony before a Senate committee last year that those requirements haven't always been met. "We can show anyone who would like to tour our area that TVA has never strictly enforced their regulations against certain operators", says J. W. Bradley, President of a group called Save Our Cumberland Mountains. Bradley went on to describe how "with every turn of the dozer's track and every bite taken by a large shovel, dragline, or front end loader, and by every blast of dynamite, we are furnished with more and more polluted water, fractured rock, loss of land and vegetation." Clearly, whatever requirements are imposed, TVA has been responsible for supporting a vast amount of strip mining, a practice which some regard as being unacceptably destructive.

\section{Nuclear future}

Those are some of the factors which have led TVA to seek a nuclear future, but it has found that it has in some respects traded one type of problem for another. So far, TVA has completed two of three units at the Browns Ferry nuclear plant, and four more units-at the Sequoyah Nuclear Plant and the Watts Bar Nuclear plant-are expected before 1980. All have experienced cost overruns, and the fire last year at Browns Ferry was a considerable setback. Stanted by an electrician checking for air leaks with a candle, the fire knocked out several safety systems, came close to causing a nuclear accident (how close is a matter of debate), and has so far shut down the plant for about 16 months. According to Seeber, the fire has cost TVA about $\$ 100$ million in repairs and lost time.

TVA is, however, fortunate in one respect. There is little grass roots opposition to nuclear power in the region, and there have been few delays caused by anti-nuclear groups forcing public hearings and challenging power plant plans in court. In part, the lack of opposition can be explained by the fact that the area has always been associated with nuclear power through the Oak Ridge National Laboratory, which provided the plutonium and enriched uranium for the Manhattan Project and which is still a major nuclear facility.

Whatever the problems, TVA has so far shown no sign of backing off from its commitment to nuclear power. In fact, it has taken two steps to enhance its nuclear future. It is now investing heavily in uranium exploration in the Western states, with a view to securing uranium supplies. And it is a major partner in the liquid metal fast breeder reactor programme, providing some money and other support for the demonstration plant to be built at Oak Ridge.

\section{TVA domination}

Aside from the controversies over TVA's energy planning, there's one broad factor which seems to bother some people living in the Tennessee Valley. TVA's operations are so extensive that it literally dominates much of the economic life of the region, and there seems to have developed a feeling that it has become a faceless bureaucracy unresponsive to local needs. The chief problem is that TVA

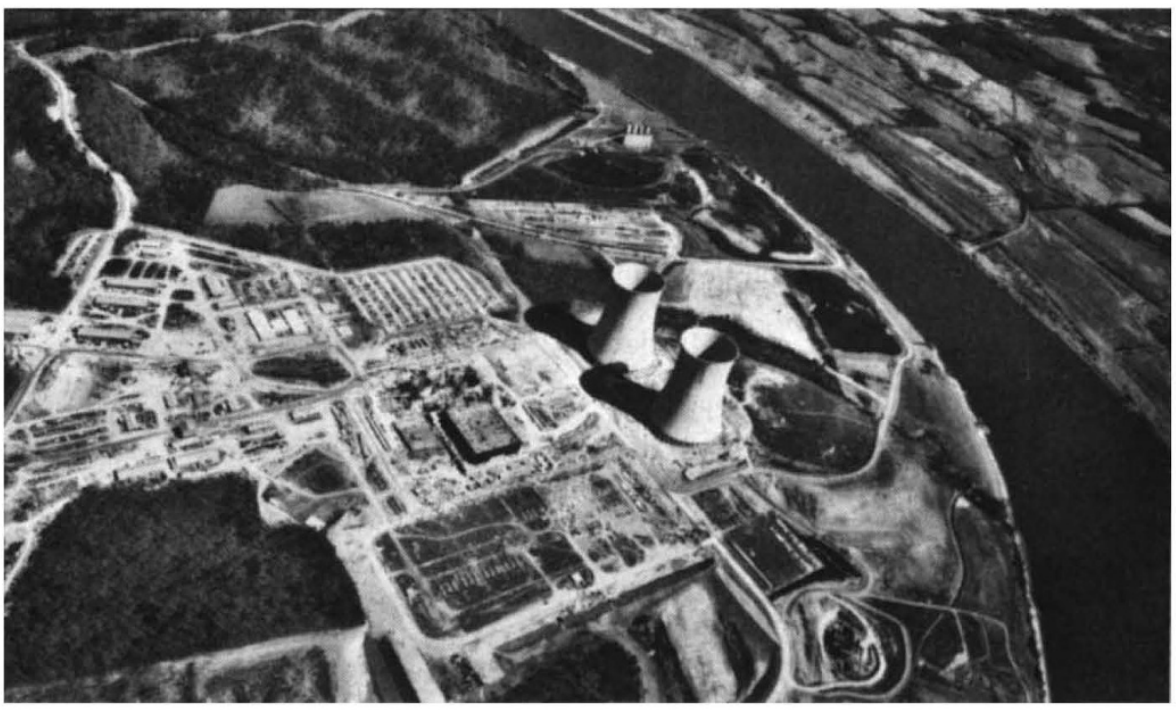

Watts Bar nuclear plant 
is a federal agency under the control, not of local legislative bodies, but of the US Congress 500 miles away.

Until very recently, TVA has been held in such affection by most residents of the Tennessee Valley-particularly those with long memories-that the remoteness of the control over the agency has been no problem. But recent sharp increases in TVA's electricity rates in response to escalating coal prices have caused some alienation and frustration because there's no local body to which complaints can be addressed. The frustration was voiced on several occasions during last year's Senate hearings on TVA, the most provocative comment being the reference to colonialism, but few suggestions for improving the situation were voiced.

Nevertheless, to most of the people in the region, TVA remains an instrument for economic progress. Certainly, few would deny that it has more than lived up to Roosevelt's hopes that it would reclaim the Tennessee Valley's land and people.

US SPACE

\section{Biological business boom}

\section{Sandy Grimwade reports from Washington on the progress of the Viking 1 experiments on Mars}

AFTER more than five weeks of practically faultless operation the Viking 1 Mars lander continues to send a wealth of geological, meteorological, biological, chemical and visual information back to Earth. The only instrument which has failed to function correctly is a set of miniature seismometers which remains locked in the safe landing position, despite efforts to free it. The other teams of scientists have, however, been kept busy by the sheer volume of information being supplied to them.

Some of the most puzzling and to the general public most fascinating data have come from the three biology experiments and the related molecular analysis of the Martian soil. Although control and duplicate experiments--the sine qua non of all biological investigation-have not yet been done, speculation is rife as to the meaning of the results so far. The scientists involved are understandably cautious about delivering a yes-no answer to the question of life on Mars, when only a small portion of their programme is complete. The results so far are certainly not what would be expected if Earth-type organisms were present, nor are they explicable in terms of "simple" nonbiological chemistry.

In the labelled release (LR) experiment, a mixture of ${ }^{14} \mathrm{C}$-labelled nutrients in a small amount of water was added to a soil sample and incubated at about $15^{\circ} \mathrm{C}$, which is $35-135^{\circ} \mathrm{C}$ warmer than the Martian surface temperature. The totally unexpected result showed a massive and rapid release of radioactivity into the gas phase-presumably as carbon monoxide or dioxide. The radioactive counts released reached 4,500 in 10 hours, levelling off after 48 hours at about 8,500. A second dose of radioactive nutrients caused an initial burst followed by a drop in the released radioactivity, after which the graph almost flattened out for the remaining four days of the experiment.

That "almost" is the tantalising part, because careful statistical analysis revealed a possible trend of very slow accelerating release of radioactivity. Unfortunately, the exigencies of operating one's laboratory by remote control across 200 million miles required the experiment to be stopped for performance of a control test with heat-sterilised soil. A later repetition of the experiment is planned with an incubation time of weeks or months rather than days. The results certainly do not look like anything one would expect from an Earth sample in the same situation. A chemical explanation involving oxidation of the labelled nutrients is at present the most popular explanation for the initial burst of activity.

The possibility that the Martian soil contains active oxidising agents was strengthened by the result from the gas exchange (GE) experiment. In this experiment the soil sample is either humidified or wetted with a concentrated "chicken soup" of amino acids, salts, vitamins and other nutrients, and the atmosphere is periodically monitored for changes in the concentration of gases by gas chromatography. The initial humidifying of the soil sample produced a remarkable release of oxygen which levelled off after several hours and remained stable for days. Wetting of the soil caused a rapid drop in the atmospheric $\mathrm{CO}_{2}$, probably due to the formation of bicarbonate in the alkaline solution, and a slower drop in the oxygen, which is speculated to be due to oxidation of ascorbic acid which is present in the nutrients. At present, $\mathrm{CO}$ is slowly being released into the atmosphere and the experiment is intended to continue for some time to see if any further changes occur. As the instrument is capable of detecting very small changes in hydrogen, methane, nitrogen and other gases, a wide range of possible biological activities could be detected.

The results of the GE and LR experiments are open to several more or less imaginative interpretations, and attempts are at present being made to duplicate the results in several Earth laboratories using simple catalysts and oxidising agents. The third experiment, the pyrolytic release experiment (PR), although perhaps the most complex technologically, is also the least equivocal when it comes to interpretation of the results. It is designed to detect the fixation of labelled carbon monoxide and dioxide in organic compounds. A sample of soil is incubated in a Martian atmosphere with added water vapour and irradiated with a simulated sunlight xenon lamp. After five days the sample is heated to $625^{\circ} \mathrm{C}$ to pyrolyse organic compounds which are trapped as vapours, and to drive off unreacted $\mathrm{CO}$ and $\mathrm{CO}$. This unreacted gas is nassed through a radioactivity detector and forms the first "non-biological" peak. The organic vapour trap is then heated to $700{ }^{\circ} \mathrm{C}$ to release and oxidise

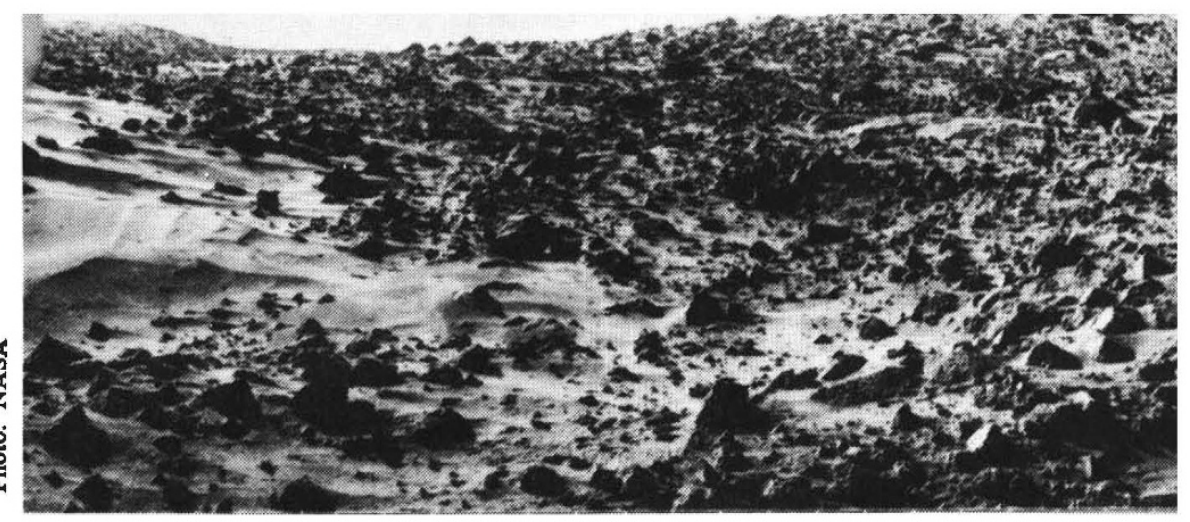

Martian dune field 